\title{
HUBUNGAN KEKUATAN OTOT PENDEK (SPRINT) PADA SISWA KELAS 5 SD NEGERI 62 KOTA BENGKULU
} TUNGKAI TERHADAP
KETERAMPILAN LARI JARAK

\author{
Velix Septra Aditya ${ }^{1, a)}$, Citra Dewi ${ }^{1)}$ \\ ${ }^{1)}$ Program studi Pendidikan Jasmani Universitas Dehasen Bengkulu \\ a)Corresponding Author: velix@gmail.com
}

\begin{abstract}
The aim of this study is to find out the correlation between leg muscle power and sprint skills on fifth grade students at SD N 62 of Bengkulu city. The method used in this study is a correlational quantitative method. The population in this study were students of class $V$ which amounted to 20 students, while the sample in this study were 20 students. The instrument in this study was a vertical jump test to measure leg muscle power and 30 meter sprint test. The prerequisite for analyzing the data used is Lilliefors as normality test and homogeneity test. The data analysis used is Product Moment Correlation analysis with a significance level of 5\%. Based on the results, it is found that there is a significant correlation between leg muscle power $(X)$ on the results of sprint skills as indicated by $r_{\text {count }}=0.97551>r(0.05)(20)=0.444$. While the implications of this study are the existence of a significant correlation between leg muscle power to the result of sprint skills, in the process of training both variables must be given each other with the same treatment
\end{abstract}

Keyword: Leg muscle power, Sprint.

\section{Abstrak}

Lari jarak pendek merupakan suatu aktivitas lari yang harus diselesaikan secepat mungkinKenyataan dilapangan selama ini di dalam pemilihan atlet lari jarak pendek dari para pelatih kurang memperhatikan faktor-faktor yang terkait dengan kondisi fisik yaitu faktor panjang tungkai dan kekuatan otot tungkai pada calon bibit atlet, pelatih hanya melihat dari prestasi yang sudah muncul kemudian dilatih lagi tanpa memperhatikan faktor panjang tungkai dan kekuatanotot tungkai. Tujuan dari penelitian ini adalah untuk mengetahui hubungan antara kekuatan otot tungkai dengan keterampilan lari jarak pendek siswa kelas V SD Negeri 62 Kota Bengkulu. Adapun metode yang digunakan dalam penelitian ini adalah metode kuantitatif korelasional.Populasi dalam penelitian ini adalah siswa kelas $\mathrm{V}$ yang berjumlah 20 siswa, sedangkan sampel dalam penelitian ini yaitu 20 siswa. Instrumen dalam penelitian ini berupa tes vertical jump untuk mengukur kekuatan otot tungkai dan tes lari jarak pendek 30 Meter. Prasyarat analisis data yang digunakan adalah uji normalitas dengan Lilliefors dan uji homogenitas.Analisis data yang digunakan adalah dengan analisis Korelasi Product Moment dengan taraf signifikansi 5\%. Berdasarkan hasil penelitian didapat bahwa (1) Ada hubungan yang signifikan antara kekuatan otot tungkai (X) terhadap hasil keterampilan lari jarak pendekyang ditunjukkan dengan $r$ hitung sebesar $=0,97551>r_{(0,05)(20)}=0,444$. Sedangkan implikasi yang diperoleh Dari hasil penelitian ini, yaitu : Dengan adanya hubungan yang signifikan antara power otot tungkai terhadap hasil keterampilan lari jarak pendek maka dalam proses latihan kedua variabel tersebut harus saling diberikan dengan perlakuan yang sama

Kata Kunci: Kekuatan otot tungkai, lari jarak pendek

Pendahuluan

Olahraga prestasi menurut Undangundang RI No.3 Tahun 2005 adalah olahraga yang membina dan mengembangkan olahragawan secara terencana, berjenjang, dan berkelanjutan melalui kompetisi untuk 
mencapai prestasi dengan dukungan ilmu pengetahuan dan teknologi keolahragaan. Oleh karena itu pemerintah harus bertanggung jawab untuk memajukan prestasi olahraga nasional di ajang yang lebih tinggi yaitu di tingkat internasional. Dalam Undang-undang RI No. 3 tahun 2005 tentang sistem keolahragaan nasional pasal 11 ayat 1 yang berbunyi pemerintah dan pemerintah daerah mempunyai hak mengarahkan, membimbing, membantu,dan mengawasi penyelenggaraan keolahragaan sesuai dengan peraturan perundang-undangan..

Selain itu, agar pembinaan olahraga prestasi dapat mencapai sasaran yang diinginkan, maka perlu diketahui faktorfaktor apa saja yang ikut menentukan prestasi seorang atlet, khususnya pada cabang olahraga atletik pada nomor lari jarak pendek. Bahwa prestasi lari itu dipengaruhi oleh kekuatan otot tungkai, dan tenaga fisik yang kuat. Kondisi fisik adalah satu kesatuan utuh dari komponen-komponen yang tidak dapat dipisahkan begitu saja baik dari peningkatan maupun pemeliharaannya. Artinya bahwa didalam usaha pemingkatan kondisi fisik maka seluruh komponen tersebut harus dikembangkan, walaupun di sana-sini dilakukan dengan sistem prioritas sesuai dengan keadaan atau status tiap-tiap komponen itu untuk keperluan apa, keadaan atau status yang dibutuhkan.

Kenyataan di lapangan selama ini di dalam pemilihan atlet lari jarak pendek dari para pelatih kurang memperhatikan faktorfaktor yang terkait dengan kondisi fisik yaitu faktor panjang tungkai dan kekuatan otot tungkai pada calon bibit atlet, pelatih hanya melihat dari prestasi yang sudah muncul kemudian dilatih lagi tanpa memperhatikan faktor panjang tungkai dan power otot tungkai. Padahal menurut hasil penelitian Rukani (2007), panjang tungkai dan power otot tungkai sangat dibutuhkan bagi seorang pelari khususnya lari jarak pendek.

Menurut pengamatan peneliti, dari berbagai perlombaan nasional, prestasi pelari sprint nasional saat ini masih minim jika di bandingkan dengan negara lain. Di dalam lari jarak pendek kekuatan otot tungkai sangat menentukan karena untuk mencapai kecepatan lari yang maksimal, panjang tungkai merupakan pendukung kemampuan seorang pelari. Frekuensi langkah tungkai yang cepat akan memberikan hasil yang lebih baik dalam pencapaian prestasi lari 100 meter. Selain faktor tersebut, power otot tungkai juga sangat berpengaruh, sebab kekuatan otot tungkai dalam lari jarak pendek dapat membantu untuk mengayunkan tungkai lebih lebar kearah depan, sehingga semakin kuat otot tungkai seorang sprinter, maka semakin lebar pula ayunan tungkai ke arah depan.

SD Negeri 62 kota Bengkulu merupakan salah satu SD yang berstatus negeri di wilayah Kecamatan Ratu Agung Kota Bengkulu. Proses pembelajaran Penjasorkes di SD Negeri 62 kota Bengkulu, bagi siswa kelas V telah diberikan materi tentang atletik. Proses pembelajaran Penjasorkes khususnya dalam atletik, dukungan sarana dan prasarana terbatas jumlahnya. Hasil pengamatan peneliti juga terlihat siswa kelas atas SD Negeri 62 kota Bengkulu dalam melakukan gerakan awalan dalam melakukan lari jarak pendek (sprint) terlihat masih ada beberapa siswa yang kecepatan dalam berlari belum maksimal, kekuatan otot tungkai yang kurang kuat, dan kelentukan yang belum baik. Untuk menghasilkan gerakan lompat jauh yang maksimal, selain keterampilan teknik juga dibutuhkan unsur kondisi fisik, seperti: kecepatan lari, kekuatan otot tungkai, dan fleksibilitas. Siswa Sekolah Dasar yang memiliki kecepatan lari yang baik, daya ledak yang kuat, dan kelentukan yang baik serta menguasai teknik-teknik dasar dalam lompat jauh, maka siswa tersebut akan menghasilkan kecepatan berlari yang maksimal.

Dari hasil dokumentasi belajar siswa kelas atas pada semester I tahun ajaran 2018/ 2019 nilai rata-rata dalam semua ranah juga belum semuanya baik. Hasil belajar siswa kelas V untuk ranah kognitif di dapat hasil rerata skor sebesar 62,7; rerata skor nilai ranah afektif siswa sebesar 63,5; dan rerata skor hasil belajar pada ranah psikomotor sebesar 64,8. Hasil belajar atletik materi lari 
jarak pendek (sprint) siswa kelas atas di semester I tahun pelajaran 2018/2019 juga masih belum sesuai dengan indikator keberhasilan belajar siswa. Indikator keberhasilan belajar siswa yang ditetapkan di SD Negeri 62 kota Bengkulu adalah minimal sebesar $75 \%$ dari total siswa dalam satu kelas telah mencapai kriteria“"tuntas".

Hubungan kekuatan otot tungkai dengan kemampuan lari jarak pendek sangat erat, karena kemampuan dalam melakukan lari jarak pendek akan membutuhkan power otot tungkai yangkuat agar hasil lompatan dapat terlaksana dengan maksimal. Namun demikian untuk mengetahui hubungan kekuatan otot tungkai dengan kemampuan lari jarak pendek siswa perlu diuji kebenarannya melalui kegiatan penelitian dalam bentuk penelitian korelasional. Namun kenyataan yang terjadi bahwa selama ini di SD Negeri 62 kota Bengkulu belum pernah diadakan kegiatan penelitian dalam hal untuk mengkaji hubungan antara kekuatan otot tungkai dengan kemampuan lari jarak pendek SD Negeri 62 kota Bengkulu perlu diuji kebenarannya melalui sebuah penelitian.

Bunn dalam Khomsin (1997:2) menjelaskan lari adalah gerakan berpindah tempat atau maju ke depan yang dilakukan dengan cepat, karena gaya dorong kaki ke belakang pada tanah yang dilakukan dengan cara mengais, sehingga pada saat berlari ke dua kaki ada saat melayang di udara. Soegito, dkk. (1992:42), menjelaskan lari adalah suatu cara menggerakkan badan ke depan, dengan melangkahkan kaki kanan dan kaki kiri secara bergantian. Menurut Syarifuddin (1992:40), lari adalah salah satu bagian (nomor) yang terdapat dalam cabang olahraga atletik.

\section{Hakikat Pembelajaran}

Hamalik (2013:57), mengemukakan bahwa,"pembelajaran adalah kombinasi yang tersusun meliputi unsur-unsur manusiawi, material, fasilitas, perlengkapan dan prosedur yang saling mempengaruhi untuk mencapai tujuan pembelajaran”..

\section{Hakikat Kekuatan Otot Tungkai}

Kekuatan otot merupakan unsur dasar dari kemampuan gerak atau kesegaran jasmani seseorang. Kekuatan otot seseorang dapat dilihat dari kemampuannya dalam mempergunakan otot untuk menerima atau melawan beban sewaktu bekerja. Kekuatan otot merupakan bagian yang penting membantu penampilan fisik seseorang. Hampir dari semua aktivitas gerak seharihari dibutuhkan kekuatan otot, sedangkan komponen-komponen kondisi fisik yang lain seperti daya tahan, daya ledak, kecepatan dan kelincahan sangat dipengaruhi kekuatan otot. dengan kata lain kekuatan otot merupakan dasar bagi komponen kondisi fisik lainnya, sehingga hal ini akan menunjang penampilan fisik seseorang

\section{Metode Penelitian}

Penelitian ini merupakan penelitian yang kuantitatif korelasional dengan menggunakan uji korelasi yang bertujuan untuk mengetahui hubungan antara variabel bebas dan variabel terikat. Menurut Emzir (2012:37) "penelitian korelasional menggambarkan suatu pendekatan umum untuk penelitian yang berfokus pada penaksiran pada kovariasi pada variabel yang muncul secara alami”. Dan tujuan penelitian korelasional menurut Suryabrata dalam Abidin(2010) adalah untuk mendeteksi sejauh mana variasi-variasi pada suatu faktor berkaitan dengan variasi-variasi pada satu atau lebih faktor lain berdasarkan pada koefisien korelasi. Dalam penelitian ini peneliti mengetahui hubungan dua variabel yang akan dikaitkan, yakni variabel bebas (kekuatan otot tungkai) dan variabel terikat (lari jarak pendek 30 meter) dan sampel yang digunakan adalah sebanyak 20 orang

\section{Hasil Penelitian}

Dari hasil pengukuran lari cepat 30 meter (sprint) yang dilakukan terhadap siswa kelas V SD Negeri 62 Kota Bengkulu terdapat skor tertinggi 62 dan skor terendah 7, berdasarkan data tersebut rata-rata hitung (mean) 36,3 dan simpangan baku (standar deviasi) 15,6. Distribusi frekuensi lari cepat 30 meter (sprint) siswa kelas V SD Negeri 
62 Kota Bengkulu dapat dilihat pada tabel berikut :

Tabel 4.2 Distribusi Frekuensi Hasil Tes Lari Cepat 30 Meter (Sprint) (Y).

\begin{tabular}{|c|c|c|}
\hline Kelas Interval & Frekuensi & Prosentase \\
\hline $7-12$ & 1 & $5 \%$ \\
\hline $13-18$ & 1 & $5 \%$ \\
\hline $19-24$ & 1 & $5 \%$ \\
\hline $25-30$ & 6 & $30 \%$ \\
\hline $31-36$ & 2 & $10 \%$ \\
\hline $37-42$ & 0 & $0 \%$ \\
$43-48$ & 5 & $25 \%$ \\
$49-54$ & 0 & $0 \%$ \\
\hline $55-60$ & 2 & $10 \%$ \\
\hline $61-66$ & 2 & $10 \%$ \\
\hline Jumbh & 20 & $100 \%$ \\
\hline
\end{tabular}

Dari tabel di atas dapat disimpulkan bahwa dari 20 Siswa kelas V SD Negeri 62 Kota Bengkulu sebanyak 1 orang siswa (5 \%) memiliki nilai antara 7-12, 1 orang siswa (5\%) memiliki nilai antara $13-18$, 1 orang siswa (5\%) memiliki nilai antara 19-24, 6 orang siswa (30\%) memiliki nilai antar 2530,2 orang siswa $(10 \%)$ memiliki nilai antara 31-36, 0 orang siswa (0\%) memiliki nilai antara $37-42,5$ orang siswa (25\%) memiliki nilai antara 43-48, 0 orang siswa $(0 \%)$ memiliki nilai antar 49-54, 2 orang siswa (10\%) memiliki nilai antara 55-60, 2 orang siswa (10\%) memiliki nilai antara 61 66.

\section{Uji Normalitas Data}

Sebelum melakukan pengujian hipotesis yang diajukan dalam penelitian ini, maka terlebih dahulu dilakukan uji prasyarat analisis data yaitu uji normalitas data. Dalam uji normalitas data ini peneliti menggunakan uji normalitas data lilliefors. Adapun hasil analisis dapat dilihat pada tabel di bawah ini

Tabel 4.3 Uji Normalitas Data Variabel

\begin{tabular}{|c|c|c|c|c|}
\hline \multicolumn{5}{|c|}{ X dan Y } \\
\hline No & Variabel & $\mathbf{L}_{\text {hitung }}$ & $\mathbf{L}$ tabel & Keterangan \\
\hline 1. & Kekuatan otot tungkai & 0,0917 & 0,190 & Normal \\
\hline 2. & Lari Jarak Pendek (Sprint) & 0,1747 & 0,190 & Normal \\
\hline
\end{tabular}

Dari tabel di atas menunjukan bahwa hasil pengujian untuk vertical jump (X) skor $\mathrm{L}_{\text {hitung }}$ 0,0917 dengan $\mathrm{n}=20$ sedangkan $\mathrm{L}_{\text {tabel }}$ pada taraf signifikan $5 \%$ atau 0,05 diperoleh 0,190. Karena $\mathrm{L}_{\text {hitung }}$ lebih kecil dari $\mathrm{L}_{\text {tabel }}$ sehingga dapat disimpulkan bahwa skor yang diperoleh dari vertical jump berdistribusi normal. Selain itu tabel tersebut di atas juga menunjukan bahwa hasil pengujian untuk lari jarak pendek (Sprint) (Y) skor $\mathrm{L}_{\text {hitung }}=$ 0,1747 dengan $\mathrm{n}=20$, sedangkan $\mathrm{L}_{\text {tabel }}$ pada taraf signifikan $5 \%$ atau 0,05 diperoleh 0,190. Karena $\mathrm{L}_{\text {hitung }}$ lebih kecil dari pada $\mathrm{L}_{\text {tabel }}$ sehingga dapat disimpulkan bahwa skor yang diperoleh dari lari jarak pendek (Sprint) berdistribusi normal.

\section{Uji Homogenitas Data}

Uji prasyarat analisis data setelah melakukan uji normalitas data maka dilakuakan uji homogenitas data dengan menggunakan uji varians (uji F dari Hevley) dapat di lihat pada tabel berikut ini :

Tabel. 4.4 Uji Homogenitas Data

\begin{tabular}{|c|l|l|l|c|c|}
\hline \multicolumn{1}{|c|}{ Variabel X dan Y } \\
\hline No & \multicolumn{1}{|c|}{ Variabel } & Varians & $\mathbf{F}_{\text {hitung }}$ & $\mathbf{F}_{\text {tabel }}$ & Ket \\
\hline 1 & Kekuatan otot tungkai & 4,7803 & \multirow{2}{*}{4,38} & 3,259 & Homogen \\
\hline 2 & $\begin{array}{l}\text { Lari Jarak Pendek } \\
\text { (Sprint) }\end{array}$ & 15,5803 & 4,38 & & \\
\hline
\end{tabular}

Dari tabel di atas menunjukan bahwa hasil pengujian varians untuk kekuatan otot tungkai melalui tes vertical jump (X) didapat skor 4,7803, sedangkan hasil pengujian varians untuk lari jarak pendek (Sprint) (Y) didapat skor 15,5803 sehinggga didapat

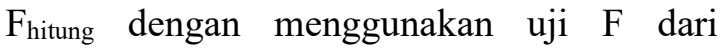
Hevley diperoleh skor 3,259. Sedangkan untuk nilai $\mathrm{F}_{\text {tabel }}$ dengan tarap signifikan $5 \%$ atau 0,05 adalah $=4,38$ karena $F_{\text {hitung }}(3,259)$ lebih kecil dari $\mathrm{F}_{\text {tabel }}(4,38)$ maka data dapat disimpulkan bahwa skor yang diperoleh untuk Kekuatan otot tungkai (X) terhadap lari jarak pendek (Sprint) (Y) memilik data yang homogen.

\section{Hasil Uji Hipotesis}

Analisis data penelitian yang digunakan untuk menguji hipotesis terdiri atas analisis korelasi sederhana. Hipotesis dalam penelitian ini adalah "Ada hubungan yang signifikan antara kekuatan otot tungkai terhadap keterampilan lari jarak pendek (Sprint) pada siswa kelas V SD Negeri 62 Kota Bengkulu". Hasil uji hipotesis dengan menggunakan analisis koefisien korelasi product moment dapat dilihat pada tabel 4.5 berikut ini : 


\section{Tabel 4.5 Koefisien Korelasi Kekuatan Otot Tungkai (X) Terhadap Keterampilan Lari Jarak Pendek (Sprint) (Y).}

\begin{tabular}{|c|c|c|c|}
\hline Korelasi & rhitung & rtabel $_{1}$ & Keterangan \\
\hline $\mathrm{r}_{\mathrm{xy}}$ & 0,961 & 0,444 & Signifikan \\
\hline
\end{tabular}

Berdasarkan hasil analisis tersebut di atas diperoleh koefisien korelasi kekuatan otot tungkai terhadap keterampilan lari jarak pendek (Sprint) pada siswa kelas V SD Negeri 62 Kota Bengkulu sebesar 0,961 bernilai positif, artinya semakin besar skor yang diperoleh maka semakin kuat hubungan antara kedua variabel. Uji keberartian koefisien korelasi tersebut dilakukan dengan cara harga $r_{\text {hitung dengan }} \mathrm{r}_{\text {tabel }}$ pada $\alpha=5 \%$ dengan $\mathrm{N}=20$ diperoleh $\mathrm{r}_{\text {tabel }}$ sebesar 0,488 . Karena koefisien korelasi antara $r_{x . y}=0,961$ $>\mathrm{r}_{(0,5)(20)}=0,444$ berarti hubungan Kekuatan otot tunglai terhadap keterampilan lari jarak pendek (Sprint) adalah signifikan. Dengan demikian hipotesis yang berbunyi "ada hubungan yang kuat antara kekuatan otot tungkai terhadap keterampilan lari jarak pendek (Sprint) pada pada siswa kelas V SD Negeri 62 Kota Bengkulu ", diterima. Artinya ada hubungan yang signifikan antara kekuatan otot tungkai terhadap keterampilan lari jarak pendek (Sprint) pada pada siswa kelas V SD Negeri 62 Kota Bengkulu

\section{Pembahasan}

Berdasarkan hasil penelitian menunjukan bahwa ada hubungan yang signifikan antara kekuatan otot tungkai terhadap keterampilan lari jarak pendek pada siswa kelas V SD Negeri 62 Kota Bengkulu, dengan nilai $r_{x . y}=0,961>r_{(0,05)(20)}=0,444$. Dengan demikian dapat disimpulkan bahwa kemampuan seorang siswa dalam melakukan gerakan vertical jump yang selaras dan sesuai dengan tujuan, tujuan yang dimaksud dalam melakukan keterampilan lari jarak pendek adalah tepat ke dalam sasaran nilai yang telah ditentukan. Aspek kekuatan otot tungkai ini dapat diukur dengan vertical jump. Aspek ini merupakan aspek penting yang mempengaruhi kualitas keterampilan lari jarak pendek, karena untuk mendapatkan kecepatan lari yang maksimal membutuhkan kekuatan otot tungkai yang besar untuk berlari.

Selain kecepatan faktor pendukung lainnya dalam berlari adalah kekuatan otot tungkai yang baik, kemudian diperlukan juga kelincahan dalam gerak dari faktor diatas dalam penelitian ini penulis hanya ingin mengetahui hubungan kekuatan otot tungkai dengan kecepatan lari, karena kekuatan otot tungkai memegang peranan penting dalam kecepatan berlari seseorang. Hasil penelitian ini diperkuat oleh penelitian Hikmah (2013) yang menyatakan bahwa Power tungkai memberikan kontribusi yang signifikan terhadap kecepatan lari 40 meter pada siswa putra SMP N 23 Bandar Lampung tahun pelajaran 2013.

Kekuatan otot tungkai adalah kemampuan otot atau sekelompok otot-otot tungkai untuk melakukan kerja atau melawan beban atau tahanan dalam waktu yang sesingkat-singkatnya. Kekuatan otot tungkai dibutuhkan hampir pada semua cabang olahraga, terutama untuk gerakan lari, melompat, meloncat, menendang, dan gerakan-gerakan lain yang melibatkan kerja otot tungkai yang dikerahkan secara maksimal dalam waktu yang singkat. Lari cepat, kecepatan lari seseorang selain ditentukan oleh faktor biomotorik seperti kecepatan itu sendiri, faktor biomotorik lainnya yang tidak kalah pentingnya adalah kekuatan kecepatan lari karena merupakan hasil perpaduan antara kecepatan dan kekuatan (power), terutama kekuatan dari otot tungkai. Kekuatan otot tungkai yang dimiliki seseorang tidaklah sama, ada yang tinggi dan ada yang rendah, tinggi dan rendahnya kekuatan otot tungkai seseorang tentunya akan berpengaruh pada kecepatan larinya. Seseorang yang memiliki kekuatan otot tungkai yang tinggi ia akan mudah mengembangkan kecepatan larinya, baik pada kecepatan reaksinya (pada saat start), percepatan gerak (pada beberapa meter pertama), kecepatan dasar (sebagai kecepatan maksimal) dan pada stamina kecepatannya (daya tahan kecepatan) jika 
dibandingkan dengan seseorang yang memiliki kekuatan otot tungkai yang rendah.

Bagi seseorang yang memiliki kekuatan otot tungkai yang tinggi akan menghasilkan frekuensi langkah yang lebih tinggi dan panjang langkah yang lebih panjang pada saat lari jika dibandingkan dengan seseorang yang memiliki frekuensi langkah yang rendah, hal ini sangat berguna untuk menghasilkan kecepatan lari yang maksimal pada saat berlari, karena kecepatan lari merupakan hasil dari frekuensi langkah dan panjang langkah seseorang

\section{Kesimpulan}

Berdasarkan hasil penelitian dan pembahasan, maka didapat kesimpuan sebagai berikut : Terdapat hubungan yang signifikan antara kekuatan otot tungkai (X) terhadap keterampilan lari jarak pendek pada siswa kelas V SD Negeri 62 Kota Bengkulu, dengan nilai $r_{x y}=0,961>$ $\mathrm{r}_{(0,05)(20)}=0,444$

\section{Daftar Pustaka}

Arikunto, S. 2006. Prosedur penelitian suatu pendekatan praktik. Jakarta: Rineka Cipta.

Rukani, 2007. Sumbangan Kekuatan Otot Tungkai dan Panjang Otot Tungkai dengan Hasil Lari Sprint 100 Meter pada Siswa Putra Kelas 3 SMP Nasima Kota Semarang Tahun Pelajaran 2006/2007. Semarang:UNNES.

Rumini. 2004. Atletik dan Metodik 1. Semarang: UNNES.

Soegito dkk. 1992. Pendidikan Atletik. Jakarta: Depdikbud.

Sugiyono. 2012. Metode penelitian pendidikan pendekatan kuantitatif, kualitatif, dan $R \& D$. Bandung: Alfabeta.

Suharsimi Arikunto, 2006. Prosedur Penelitian. Jakarta: Bina Aksara. 